\title{
Feminism in Philippine Mainstream Short Stories in English
}

\author{
Jeanette G. Dials
}

\begin{abstract}
The study analyzed the award-winning short stories in English using Cheri Register's Feminist Perspective Criticism. Specifically, it determined the images and emerging roles of women as reflected in the short stories and the motives and reasons behind these images and emerging roles.

Only the short stories with female characters, major or minor were the subject of the study.

The Filipino woman manifested the following images: submissiveness to authority, frailty to human desires, assertiveness to socio-cultural conditions and responsiveness to the changing times. Almost all the women characters in the short stories under study are modern in their outlook in life. It can be gleaned that women are breaking loose from their historic cocoon which contained them for many years. They can now control their own emotions and rule their own lives.

Women are no longer confined to their traditional roles as wife and mother in the home. They have asserted their equality in almost all aspects of life. They have confirmed that sex is not a determinant of a person's capacity and ability to stand as an individual.

The study claimed that the score or two decades, 1981-2000 had been a time for Filipino writers to give another light to the status of women in society-that is espousing salient features of feminism.

The study further confirmed that the economic conditions in the woman's world, dynamic social situations and emergence of moral concerns paved way for the surfacing roles and images of Filipino women.
\end{abstract}

Index Terms-Short stories, literary criticism, feminism, Asian literature.

\section{INTRODUCTION}

The Filipino women today are faced with vast challenges in this complex world. Gone are the days when they simply would stay in their homes attending to their household chores and other domestic activities. They have become partners of men to meet the challenges of life. With the passing of an old era and the ushering of a different age with its distinctive political, economic and social conditions and forces, an ideological revolution is needed, a revolution in the ideology of gender roles current in culture, a revolution in concepts of gender identity [1].

In the sexist society where men are considered as the superior sex, the image of women as housekeepers (or the inferior sex) is almost indelible. In the Philippines, the colonial years have relegated women to secondary positions in society and the nation's changing history has failed to completely erase the general view that the women's place is

Manuscript received February 15, 2017.

Jeanette G. Dials is with the Graduate School of Mariano Marcos State University, Philippines (e-mail: jd_0256@yahoo.com). the home. Although Filipino women today generally enjoy a relatively high status, there are still some areas where they are considered inferior to men.

Over the years, women have started to create their places in the sun. Obviously, they have realized that they are no longer mere cogs in a wheel but already vital parts of a whole. They now count themselves as equal partners of the male species and can contribute tremendously for the betterment of society. They are no longer regarded as second-class citizens or subordinates or helpers of men. They no longer stay exclusively in the homes for they, too, can distinguish themselves in all fields of endeavor be it in government or non-government organizations, business, industry, social work, and even in the military.

Vogue Magazine reports that the fashion world is eagerly embracing Asian culture that is, entering a century when a truly integrated and universal fashion is seen [2]. This Asian invasion of a cultural kind focuses attention on Asian women's unique difference. Today, there emerges the enlightened Filipino woman, sensitive not only to her needs but also to that of the society, aware of her potentials both as a woman and as a total human being capable of playing a fuller role in the improvement of society.

The process of creating this new kind of woman was unthinkable without the support of ideas and organizations which advocated justice and rights for women. The emergence of feminist consciousness rested on the existence and continuity of woman's rights, conventions, the suffrage and woman's club movements, and feminist organizations.

In the Philippines, the signing into law of President Corazon Aquino of the Women in Development and Nation-Building Act or Republic Act 7192 gave women an equal legal status with men. This is a start towards changes on how women are thought of, looked at and treated in the society [3]. Republic Act 7192 guarantees removal of gender bias in government offices, equal and direct participation of female employees in government projects, availability of voluntary membership in the SSS, GSIS, or PAG-IBIG Fund for full time housewives, capacity to act and enter into contracts, equal right to act as incorporators, ability to secure loans and enter into credit arrangements, legal capacity to apply for passports, secure visas and other travel documents without need to secure husband's consent, equal access to government and private sector programs granting agricultural credit, equal treatment in agrarian reform and land resettlement programs, opening doors of the PMA, and PNP, and similar institutions to women. The changing status of the new Filipino woman is reinforced by how contemporary writers portray her in literature. Literature, serving as an expression of society, portrays the female character in a new 
perspective: autonomous, decisive, capable and professional. Seeing the Filipino woman in that light is made possible by the emergence of a new approach in literary criticism - the feminist criticism [4].

The female literary tradition comes from the still evolving relationship between women writers and their society. Moreover, literary historians cannot treat the female imagination as a romantic or Freudian abstraction. It is the product of a delicate network of influences operating in time, and it must be analyzed as it expresses itself, in language and in fixed arrangement of words on a page, a form that itself is subject to a network of influences and conventions; including the operations of the marketplace. Engraved in the tablets of Philippine history are the $80 \mathrm{~s}, 90 \mathrm{~s}$ and early $20^{\text {th }}$ century. This is the generation that made people see the arduous journey from dictatorship to the long-sought and cherished return to democracy. It is while on this journey that artists rose to shape and mold anew the nation's awareness of stirring social changes. This was the score of hopes and dreams yet bore its share of pain and tribulation as well. Significant human experiences and events from this era are the threads the Filipino writers began to weave into a tapestry that displays a nation's courage and victory, the nobility of the human spirit and resilience of the artist's creativity. The weave is a valuable document of history.

It is in this light that the award-winning stories are taken as subject in this study.

\section{OBJECTIVES OF THE STUDY}

This study analyzed award-winning contemporary Philippine short stories in English written by both male and female writers using Cheri Register's Feminist Prescriptive Criticism.

Through an in-depth study and analysis, it sought to:

1) find out and discuss the images of Filipino women as depicted in the mainstream Philippine short stories in English;

2) discuss the emerging roles of Filipino women reflected in the short stories;

3) identify the motives and reasons behind the images and emerging roles of Filipino women.

\section{REVIEW OF LITERATURE}

\section{A. Images and Roles of Women}

The image of the Filipino women for the past two decades was influenced by the changes in the Filipino women's lives finding expression in the already highly developed short story in English. The images of strong women are reflected in the short stories, an indication of the growing consciousness of women that they have found among themselves. The contemporary Filipino short stories in English reflect women's role in social development and cultural growth [4].

Garcia [5] studied the leading Filipino woman characters in the four novels of Liwayway A. Arceo. She unfolded a new image of a Filipino woman - assuming, as depicted in the heroines of Arceo's novels. Character traits that are unmistakably Filipino are best illumined since such traits have been faithfully delineated by each of the heroines on the four novels. Moreover, said study greatly dealt with the many instances the heroines were able to redeem themselves.

The present study is similar to Apostols's [5]. since both focused on the new image being assumed by the contemporary Filipino woman as depicted by the women characters in the text. However, the latter also considered not only the protagonists but also the antagonists. Prize-winning short stories that were considered for analysis were not only written by female writers but also of male writers. Through this, the researcher believed that she would more likely present an unbiased as well as balanced view on the Filipino woman.

De Guzman [6] identified the types of women as seen through the female characters of F. Sionil Jose's twelve stories. This study dealt with the five types of women as depicted in Jose's fictive writing: martyr, victim, bitter or angry woman, woman in transition and the healer. Since the women portrayed different roles in Philippine society, De Guzman stated that they could be any of these: domesticated, kept woman, pleasure seeking or revolutionary.

Slightly similar to the researcher's study is De Guzman's choice of a male writer in F. S. Jose. The present researcher however, looked into the short stories written by both male and female writers who have a more in-depth study on the extent of feminism in contemporary times.

De Guzman pointed out that F.S. Jose maintained a balance in the projection of his female characters to depict his pro-feminist stand and his being a male writer; that of showing the holistic view of the person through her strengths and weaknesses.

Arellano's [7] “Contemporary Images of Filipino Men and Women" as depicted in the Liwayway Magazine stressed one point. She claimed that the short stories represent the complex interrelations of political and social forces in a society. She emphasized that the stories foreground the discourse that even the individualistic, educated, modern career woman accepts that it is her natural fate to perform the "triple burden" of mother, care-giver and breadwinner but can also willingly defy convention if only to assert her mother roles.

Likewise, she mentioned that the male professional characters depicted in the short stories are represented to be decisive, intelligent, successful in their careers, faithful, responsible, industrious and chivalrous thus, affirming the stereotype idea of patriarchy that men are given to intelligence, rule, warfare, and other altruistic projects expected to serve mankind and promote civilization.

Arellano further noted that feminist authorship in Liwayway although still a minority, breaks the literary silence of women by taking the discourse of "otherness" of narrative, point of view, characterization, tone, and focus in the telling of a story. She further affirmed that radical feminist texts promise to evolve from the printed work of short fiction in Liwayway

Serrano [8] claimed that the Filipino woman as depicted in the contemporary novels has varied images under which she could be categorized; the ever-sacrificing wife, the femme fatale, the nymphet, the over ambitious shrewd politician and the committed street parliamentarian. She pinpointed the fact 
that the Filipino woman has changed greatly her image from the traditional coy Maria Clara to the modern Filipina, daring and committed due to the varied factors that greatly influenced the change of image such as socio-economic and political conditions, as well as personal ambitions.

The researcher's study is similar in this light: that of looking into the possibilities of change in the woman as portrayed by mainstream writers of contemporary times.

\section{B. Feminism Discussed}

Feminism is a vital engaging, and exciting perspective from which to view virtually every facet of life. Feminism is so integral to life that one cannot imagine not being a feminist. This perspective may seem surprising given that feminism has such negative connotations in popular culture. When many people think of feminism and feminists, they envision angry women- perhaps in combat boots, flannel shirts, and no makeup- who spout harsh, anti-male slogans or otherwise assert power over men. Although some feminists may engage in some of these activities, not all feminists do. What is important to note is that there are many kinds of feminisms and feminists, and feminism is a much more complex mode of being in the world than any of these images suggest.

Most definitions of feminism are ones that are believed by many individuals who would support if they understood feminism apart from its stereotypically negative associations. West [9] suggests that self-definition is central to her understanding of the term: "I myself have never been able to find out precisely what feminism is: I only know that people call me a feminist whenever I express sentiments that differentiate me from doormat." Women's articulations of their own experiences and ideas and their claims to the right to determine how their lives will proceed, then, are key aspects to feminism.

Other definitions of feminism focus on the concept of equity, with a goal of reorganizing society on the basis of equality for the sexes in all areas of social relations. Definitions rooted in equity focus on the achievement of equality for women with men and the development of opportunities for women's expression and self-fulfillment in all realms of life, without the constraints of gender expectations. Feminists who embrace this definition of feminism seek an equal share of the opportunities to which men have access.

Other feminists are concerned with the development of alternative social systems and ways of being in the world-ways that are grounded in woman-centered principles and values. Some of these feminists separate from men in order to discover the kinds of lives that are possible for women outside of patriarchy. Still others believe that separation from men is infeasible or unrealistic and that a woman-centered perspective can be enacted in the current world despite the on-going persistence of patriarchy.

Many feminists now expand the use of the term feminism to include eliminating the oppression of all people who are marginalized by the dominant culture, including but not limited to people of color, people with disabilities, people of different ages and socioeconomic classes, and lesbians and gay men. Such definitions of feminism suggest the treatment of all humans in accordance with such feminist values as respect, caring, reciprocity, self-determination, and interconnection. Some feminists extend these values to all creatures on the planet as well as the planet itself. In other words, they see all living beings as entitled to live life fully and to be affirmed and valued as unique and significant contributors to the universe.

Hooks [10] defines feminism as the struggle to end sexist oppression. She explains that to be feminist in any authentic sense of the term is to want for all people, female and male, liberation from sexist role patterns, domination and oppression. It is a struggle therefore to end domination.

These myriad definitions of and perspectives on feminism suggest that there are a variety of kinds of feminisms and feminists. This variety opens up choices and possibilities and speaks to the very nature of feminism. It is rooted in choice and self-determination and does not prescribe one official position that feminists must hold. Feminism is also an evolving process that necessarily changes as conditions in the world change and as feminists develop new understandings.

Feminism is a commitment to a set of principles or values. The feminist therefore is committed to enacting in the world the values of self-determination, immanent value, affirmation, mutuality, and care. She is committed to eliminate oppression, domination and hierarchy in all of their manifestations. It is a way of living one's lives and acting in ways that allow others to make choices that affirm them and their perspectives, and that do not oppress and exploit [11].

\section{Importance of Feminism}

K. Floss and C. Griffin in their book Feminist Rhetorical Theories point that feminism is an important perspective for at least it validates values and experiences often associated with women. Some of our most meaningful experiences have involved women, and feminism celebrates and honors such experiences [11].

Feminism is also important because it gives voice to individuals marginalized and devalued by the dominant culture and thus provides a more holistic understanding of the world. Feminism takes seriously not only the experiences associated with women but also those of all marginalized groups, whether people of color, people with disabilities, lesbians and gay men, or any other group that is not featured in the dominant culture. Feminism takes seriously their perspectives and suggests that these perspectives are as valuable as those that characterize the dominant culture. The result is a greater repertoire of options for living and communicating to all individuals.

Furthermore, feminism is important because it is believed to establish and legitimize a value system that privileges mutuality, respect, caring, power-with, interconnection, and immanent value. These values stand in direct contrast to those that characterize the dominant culture- hierarchy, competition, domination, alienation, and power-over, for example. Feminism therefore, offers a model for different ways of living in the world.

To Hooks in the Feminist Rhetorical Theories [10], feminism does not only aim at eradicating the ideology of domination but also functions as a constructive, proactive force. It seeks to transform relationships and the culture so that alienation, competition, and dehumanization that 
characterize human interaction can be replaced with feelings of mutuality, intimacy, and camaraderie.

Feminism offers women not liberation but the right to act as surrogate men.

\section{Methodology}

This study made use of the descriptive and analytic methods of research. The descriptive method has for its purpose to describe phenomena, in contrast to ascertaining what caused them or what their value and significance are. It requires the gathering of facts for description. In analyzing the short stories, something is described in terms of component parts whereby the roles, emerging roles and motives of characters are analyzed based on their lines, situations and other elements in the stories.

The following steps were observed in the course of the study.

1. Reading of related literature and studies. The researcher went through extensive reading of references in the different libraries of universities and colleges in Region I, Cordillera Autonomous Region and Metro Manila including the CCP library, National Library and UP Center for Women Studies. She also referred to some magazines, newspapers, books, reviews, articles in the Internet, periodicals, government documents, thesis and dissertations. Through these, she was able to get a wider knowledge of the topic under study.

2. Determining the short stories for analysis. The researcher looked for the list of Philippine short stories in English written from 1985 to 2005 from available books that are written by mainstream writers, both female and male. She chose the first prize-winning short stories in English written from this period because of their literary merits. She read the stories to ensure that they project female consciousness, as well as, reveal perceptions of the Filipina as to her temperament, image and status in Philippine society from the perspective of both the male and female writers. She noted down the title of the story, title of the book, author and the date of publication of the book. The details of which were needed in the course of the study.

3. Reading of the short stories. The researcher read the stories for the second time, this time for understanding. A thorough investigation of the story was conducted in her third reading specifically looking into the feminist touches of the stories. The stories that were found out to have no female characters were not anymore considered in this phase.

4. Analysis of the short stories. The researcher at this stage analyzed the short stories one at a time using the prescriptive criticism approach. The analyses ranged from citing lines/paragraphs to critical analysis of the situations/incidents in the stories.

5. Holistic evaluation of the short stories. The researcher at this point wrote an over-all evaluation of the stories centering on the images of women and the contemporary roles of women that could be in the short stories under study. After eliciting the images and emerging roles of women, the researcher looks and finds out the motives behind such images and roles.

\section{FINDINGS}

Values, issues, morals, laws, traditions and developments of the society may be clearly gleaned from literature as it captures the different human experiences of people. Likewise, the people's sentiments, ideas, feelings, and opinions are reflected. It is safe to claim therefore that it is through literature where these are preserved from one generation to the other. And one way of transmitting such is character stereotyping. In novels, short stories and plays, the female has been made to act out roles that society has traditionally reserved for women - the obedient wife, the loving mother, the patient teacher, the responsible elder sister, all of whom are ordained by God and society to render service where and when needed [12].

Likewise, she is pictured and described as subservient, emotional, sentimental, irrational and docile. In the short stories under study, the kinds of roles and images they portray vary. They range from the subservient to the assertive, conventional to modern, prostitute to decent, pessimistic to optimistic, inferior to superior (as to men). The images they project and roles they play in these stories have underlying reasons. Each has a story to tell.

In the study, the following images of women can be gleaned: submissive, frail, assertive and modern.

Submissiveness. In Hog Heaven, Jessie B. Garcia presents Melissa, the female major character, as the daughter of a drunkard who lives at the topmost floor of an old abandoned four-storey building in Quiapo that overlooks Quezon bridge from one angle and the murky Pasig River from another. The building is just awaiting the wrecker's ball. She never says any word to his father despite the very poor condition they are in. She just allows circumstances to operate in her life. She just continues to serve him every time he is drunk.

Melissa is alone and longing to be loved. She may not accept it but her actions would speak for it. Instead of letting her father know that a man is pestering her, she decides not to tell him simply because she felt it was a nice feeling and that she has never experienced being caressed.

At one point, the narrator can not control his feelings for her, of course mixed with sympathy and apathy for her as she sees her sobbing so he wanted to shield her from impending miseries. He passionately kisses her face drenched with tears.

Her innocence makes her simply succumb to the situation. She can not refuse the narrator in his sexual advancements. Her submissiveness affects her as a person. She could not resent the wills of the narrator. She becomes blind to the reality that he could not be with her forever, that he has other priorities in life. She is so passive. She is too weak to make a stand and show resentment.

Another degree of submissiveness is evident in the case of Mrs. Quinton in the Oldtimer written by Jose Y. Dalisay. She accepts her fate as the partner of her husband in life. She submits to the role of a wife, his inspiration. In a way, Edna of Reprieve also displays this image. Her silence every time her sick husband nags him speaks that she still respects and considers the status of a man in her home. Likewise, she displays tremendous compliance to her husband's wishes when he asks her to do some tasks for him. 
Frailty. Merlie gives a glimpse of the world of prostitutes. It is human frailty and the need to survive that pushes her to prostitution. The story is a series of impressions and vignettes about various prostitutes and about the squalid life of the city. The story gives a panorama of the world of prostitutes, their conditions, their hopes and their dreams, their needs, their preferences. They are women who ply the night to trade flesh for their survival. These impressions and vignettes surround Merlie, and her attempt to go to Japan. She typifies and concretizes the grim realities of the city life of the under privileged, particularly the prostitutes.

The story also shows the commodification and confinement of woman in the persona of a prostitute. This therefore is a manifestation that she is a commodity. She is "sold". Thus, she is subordinate to the man who buys her.

Merlie is confined not only to the brothel but to little cubicles as well. She may have a private space but she has no sense of self-ownership because she is open to all men. Therefore, she can not move on her own, that is, she only moves upon the dictates of men.

Luisa in The Flight is so innocent yet ever curious who became very homophobic in learning about the death of his uncle. He has lived in pure confusion.

In another light, Melissa is a character who displays a weak disposition. She is a pitiful creature who has no control over her destiny. Unlike Merlie who is exposed to the stark challenges and bare realities of life due to the nature of her work (prostitute), Melissa is not exposed due to her physical impairment as mentioned earlier. Despite this weakness, she emerges a fighter. When she senses that something immoral is happening between the narrator and Toti, she decides to keep her distance from him.

Assertiveness. Susan Lara presents her lone female character vis-à-vis two male characters who regard her as 'built to last'. Edna, a doctor is a caring wife to Leo and a concerned mother to Sandy. While her husband is recuperating from his injury, she takes her husband's schedule of tending to patients with emergency cases.

She is regarded as a man's equal. Though Sandy vehemently protests her being on the driver's seat, she still insists. Almost in all instances, she just keeps her calm, eyes set still on the road, unwavering almost unblinking, a manifestation of her being firm, steadfast and definite.

One thing positive with Merlie is her strong desire to better her craft, to better her life. She looks forward to becoming an international, honest-to-goodness, fresh-from-Japan star.

Merlie believes that her being able to secure all documents needed for her Japan stint is an 'act of God and her presentation of passport and ticket was accompanied by a memorable discourse on the power and mystery of faith. To some extent, Merlie is the embodiment of what to feminists a woman should be - aggressive, assertive, strong and determined.

Modernity. Having an illicit affair with an eighteen-year old teen-ager, Prof. Leticia Alva moves out of the conventions of the society to which she belongs. Her reaction on the nature of things speaks of her pathological innate destructive nature to corrupt the male of the species yet considers them an important possession to please her. Our Lady of Arts and
Letters presents scenes in the life of a woman who lives in an era when prevailing ideas about women may seem unacceptable even in the present time. Leticia is a representation of a Filipino woman breaking free from the social conventions that bind her. She is unlike Melisa of In Hog Heaven who easily succumbs to authority and who gives in to human frailty.

As a teacher Leticia employs modern techniques in teaching. Actually, Alan learns a copious source of information about Leticia from her students.

The Emerging Roles of Women. Women are identified according to the roles they play in society although in reality, there is no common accord regarding their role. There are some who think that their place is still the home with the traditional things related to it, even if they have to admit that they can opt for work, in order to help shoulder the many expenses of the family. Others think that the woman should assert her rights vis-à-vis man.

The women in the short stories under study disclosed these roles: traditional/domesticated wife or mother, women without men, pleasure seeker/prostitute, and revolutionary/activist. These female roles confirm the roles manifested by women in the study of Arellano [7] and De Guzman [6]. It should be noted that some of the women characters in the short stories under study have more than one role.

Wife/mother. Foremost of these wives in the story is Edna, a devoted wife and a caring mother. She is a middle class working wife who balances her responsibilities in the home and in her new work. Despite the emotional and psychological pressures brought about by her husband's temporary incapability as provider, she remains very calm and tolerant of her husband's misdemeanor. Another picture of a wife is Mrs. Quinton in Reprieve. She is painted as the beautiful wife who inspires her man. Other than the descriptions given by the narrator with the pictures he receives from Charlie, only a few could be said about her.

A different concept of a wife is depicted in Our Lady of Arts and Letters. Leticia never cares for her husband. She rather exchanges him with anybody who fits her fancy. To her, the role of a wife ends when she is no longer contented with her mate.

Women without Men (Independent). Leticia defies the conventions of a wife. She chooses to live separately from her husband because she realizes that he is no longer the person who could satisfy her needs. She thinks that she is already mature enough thus, her preferences have changed tremendously. Instead, she concentrates on her work though she seeks the company of a younger man every time she craves for the flesh.

At the start of the story In Hog Heaven, Melissa feels helpless and submissive to her father and the narrator. However, when she sees that an illicit relationship is going on between Toti and the narrator, she decides to confine herself in her room, a manifestation of her decision to stay away from him, and to start anew without him. Merlie is also another character who despite her being a prostitute remains directed in her path- that is to go to Japan and become an international star. 
Pleasure Seeker/Prostitute. The short stories under study present two types of women under this category. One is a woman who simply seeks for pleasure and a woman who gives pleasure with a corresponding price. In all societies, prostitution has become one of the most evident forms of sexual exploitation. A prostitute is paid in every smile and every act she does to fulfill the desires of her mate. There is Merlie who desperately searches for a life entirely different from what she has in Harem. Though it should be noted that not all of these prostitutes are able to get their desires and not all of them turns out desperate. There is Gina who gives birth to a baby without brain and then dies a year later from a poorly performed abortion; Rose from Dagupan whose husband is a roadworker is run over by a streamroller; Connie, Merlie's friend and constant pen pal is now happily and successfully working in Japan as an entertainer; Ging, Judy, and Dianne who used to work hard as masseuses but now have successful lives outside the business. There is Leticia who is a plain flesh pleasure seeker. This is a very surprising behavior because she is a well-respected teacher of Arts and Literature in her school, a person who is supposed to display moral attitude in her society.

The case of Melissa is different. She seeks pleasure from someone very dear to her or just anyone who shows interest in her.

Revolutionary/Activist. De Guzman [7] considers a revolutionary woman brave and courageous as she fights for a change for herself and for others. She is aware that her assertion is against the traditional roles she is expected to handle. Since she is educated and resourceful, she turns to be more productive. In Reprieve, Edna slowly lets her husband accept that she could also be a good substitute for his work. However, she may have made her protests in silence, she is able to get the nod of her husband. This protest of silence and avoidance was also clearly exhibited by Melissa in Hog Heaven. Most noteworthy of all the female characters in the short stories under study is Leticia Alva. Despite her colleagues not liking her, she still pushes through with what she thinks was good for her to do as a teacher. She introduces new techniques in her classes that make students appreciate her all the more.

Motives and Reasons behind the Images and Roles of Women. The Philippines has been subjected to different cultures and traditions brought about by the successive colonial conquests starting with the Spaniards then the Americans and later the Japanese.

During the Spanish conquest, women were the Maria Clara type; submissive, passive and docile primarily because they were not given the chance to seek for education. They have accepted their fate thus considered themselves inferior to men.

Then came the Americans who introduced liberalism. Women began to assert their rights and they were slowly recognized as men's equal. Although their image changed, their roles have remained the same. She still performed her domestic and traditional roles in the home.

The political uprisings of the 70's and the 80's and 90's however awakened them from their deep slumber. They joined demonstrations on the streets fighting for issues that beset them. Together with men, they protested against social and political issues. They learned to belong to organizations and movements.

The underlying motives and reasons behind these changes in women's roles and images are documented in literature. This is because literature has been one of the greatest vehicles in transmitting the changes and issues in the society. The sensitivity of the writer is seen in his/her works as he/she relates the ideas and every important thing to some definite principle of beauty and justice. Indeed, the greatest task of the writer as Salvador Lopez claims in his Literature and Society, is to be the greatest social catalyst.

The images and roles portrayed by the women characters in the short stories under study support Lopez' claim. The writers of these short stories created a woman because of the following motives: moral condition, economic condition, and social condition.

Economic. It has been already established in the earlier part of the study that the contemporary woman is no longer confined with her traditional and domestic roles. Because of the growing needs of the family, she is compelled to perform other tasks outside the home just so she could earn a living. Melissa, despite her inequities and illiteracy, has to earn a living. Edith in The Axolotl Colony equipped herself with the necessary skills to land on a good job in the US without expecting anything from the husband.

Financial needs push the women to join the labor force outside the home. But of course this situation should not be viewed in just one direction only. While it is true that women join the workforce to meet the demands of the times, there are still others who go out of the vicinity of the home simply because they want to get even with their male counterparts.

Susan in Reprieve has another case. She took the responsibility to attend to her husband's patients because he is sick; otherwise, they may not have anything to sustain their needs.

The growing population, the economic crises and the consistently increasing rates of unemployment and underemployment among women have led them to engage in domestic services and sex trade.

Merlie, due to her poor economic status dreams of going to Japan. While still in the country, she and other women in Harem chose to work in 'cubicles' and offered their own flesh for a measly sum of money to earn a living.

This is also the reason why Mrs. Quinton accepted Charlie as a husband in Oldtimer. Though very fresh and young, she had Charlie as a husband because of his being a New Yorker with dollars. This condition is very rampant in the Ilocos provinces where young girls are made to marry old balikbayans.

This is the same reason that led to Gina's abortion and eventually her death in Merlie

Social. The society plays a major role in shaping the real identity of women and in alleviating their conditions. Melissa for example, lands into a depressing condition due to circumstances beyond her control. The greatest factor that influences her is her being a product of a broken home. She secludes herself from people and has remained within the confines of the nearly dilapidated building. Added to this is 
her being blind causing her immobile. She needs to survive. Aside from this basic need, she also longs to be loved and respected by other people, something she could not get because of her inequities.

Another aspect under social condition that needs to be looked into is sexism. Calling women "girls" in Merlie is an act that makes women diminutive and powerless. Describing Merlie as a "masseuse-plus with a routine guaranteed to make a man lay a five-pound egg" is a commodifying and despotic way of looking at her- simply focusing on her ability to give pleasure. She is euphemistically described as "she was no Miss World", "she cuts a lousy profile", "nobody gave her a second look", and her inordinate plainness went well with her darkness". The mother in Trouble in Beijing was just relegated in the corner as the helper of her husband.

Sexual exploitation is a sexually abusive act committed for personal interest against any of the sexes. An example of this is prostitution- a condition that continues to discriminate and degrade women. Merlie showcases this.

What is seen in Our Lady of Arts and Letters is different. Though it involved the flesh, Leticia is not motivated by monetary reasons; instead, she is forced by her husband to mar her reputation.

Because women realized that their role is stereotyped and is imposed by the society, they slowly became aware of the discriminatory practices engendered by social structures.

They became vocal, articulating their demands and asserting their rights.

Moral. One factor behind the new images and roles of women in contemporary times is the double standard morality which the society adheres to. Webster's Dictionary defines double standard morality as a set of principles that applies differently and usually more rigorously to one group of people or circumstances than to another. This is a code of morals that applies more severe standards of sexual behavior to women than to men. This is manifested in the case of Leticia. She talks of the times she was bored when she and her husband went to the province thus the husband permitted her to go out with a man. Aside from the view that the sexual act should only be practiced by married couples, there is also the view that it is only the man who should be aggressive in a relationship and who is capable of inflicting pain whether physical or psychological on the woman. In such context, Leticia, Merlie, and Melissa suffer much although Edith was the one who made his man suffer by divorcing him. Society as represented by other characters in the short stories fails to see and understand women as persons with equal rights. Instead of sympathizing with them, society on the whole manifests only a degrading attitude and prejudice against women.

\section{CONCLUSIONS}

In the light of the findings, the following conclusions could be drawn:

Literature has indeed become the expression and interpretation of the society. Social reality is depicted in literature. With the short stories under study, it shows that the woman has considerably changed in terms of her image and role. She could now leave the home to work. She is uprooted from her age-old place of work which is the home. Foremost among which is her new feeling of independence.

Most of the women in the short stories under study are of high order: intelligent, assertive, self-willed. They control their own emotions and rule their own lives. They possess the courage and the independence of mind to rebel against stifling convention. They strive to be true to themselves rather than adopt a role imposed by society.

In the light of the findings, it could also be said that women are no longer confined to their domesticated and traditional roles as a wife/mother. It is obvious that women of today count themselves as equal partners of men who can make valuable contributions to mankind, and not to be considered subordinate.

\section{RECOMMENDATIONS}

Based on the findings and conclusions drawn, the following recommendations are forwarded:

One immediate need today is to cleanse the negative image of Filipino women locally and internationally. Literature and other forms of arts should depict the true image of the Filipino women today so that her traditional image shall vanish. Concerned women organizations and even literary associations and even the media and other organizations should ensure that their representation is not biased.

In these modern times, when women are the focus of a culture that has been, and is still dominated by men, there is a need for a re-reading or a reinterpreting of literature to determine their true value from a feminist standpoint.

There should be a further study on the women characters of the Philippine mainstream writers for novels and short stories to further look into the images and emerging roles of women. In this way, their nature and their status in the society may be reassessed. Likewise, an analysis of men characters be also conducted vis-à-vis the woman.

A study on the women characters of other mainstream writers is also encouraged. Through this, women may be better understood. This is also a way of further looking into her emerging roles and new images especially in this new era.

\section{REFERENCES}

[1] A. Oakley, "Gender, methodology and people's ways of knowing Some problems with feminism and the readings in debate in social science," Sociology, vol. 32, no. 4, pp. 707-731, 1998.

[2] G. Howell. "Eyeing the east," Vogue, May 1994.

[3] A. Maranan. "Toward a feminist consciousness in the socio-historical analysis," Quezon City: Women's Resource and Research Center, Maryknoll College Foundation Inc., 1997.

[4] G. Nayan. The Image of Filipino Women in the Carlos Palanca Memorial Award-Winning Short Stories in English 1973-1983, Unpublished Thesis. Centro Escolar University, 1995.

[5] V. Apostol. Pagsusuring Feminismo at Dekonstruksyon Sa Mga Maikling Kuwentong Iluku, An Unpublished Thesis. Mariano Marcos State University, 2003.

[6] T. De Guzman. The Women of San Francisco Sionil Jose: A Woman's Reading, Unpublished Thesis, Baguio: Saint Louis University, 1995.

[7] A. Arellano, Contemporary Images of Filipino Women and Men as Depicted in Popular Short Stories in Liwayway Magazine for 1976-1991, Unpublished Dissertation. University of the Philippines, 1994.

[8] W. Serrano. Images of the Filipino Women in Selected Contemporary Novels, Unpublished Thesis. Baguio Colleges Foundation, 1991. 
[9] M. Eagleton. Working with Feminist Criticism, Massachusetts: Blackwell Publisher, 1996.

[10] B. Hooks, Feminist Theory from Margin to Center, USA: South End Press, 1984.

[11] K. Foss and C. Griffin, Feminist Rhetorical Theories, USA: Sage Publications, 1999.

[12] S. Reyes, Kritisismo: mga teorya at antolohiya para sa epektibong pagtuturo ng panitikan. Anvil Pub. Co.

Jeanette G. Dials was born in Quezon City, Philippines on September 13, 1969. She finished her master of arts in education major in English language and literature at the Mariano Marcos State University Graduate School, Laoag City, Philippines in 2006. She has already completed the academic requirements leading to the degree doctor of education major in education management.

She has been teaching English language and literature for 27 years at the
College of Teacher Education, Mariano Marcos State University Laoag City as an associate professor. She is one of the associate editors of the College of Teacher Education Research Journal and the former department head of the Education Department of the Provincial Government. Her research interests include social and cultural issues, language and literature and curriculum.

Prof. Dials is a member of the Network of Outstanding Teachers of the Philippines (NOTED), International Debate Educators Association, Linguistic Society of the Philippines, College Educator's and Teachers Association (CETA). She is the 2008 Most Outstanding Teacher of the Philippines, 2009 Most Outstanding School Paper Adviser of the Philippines and 2009 Outstanding Laoageno. 